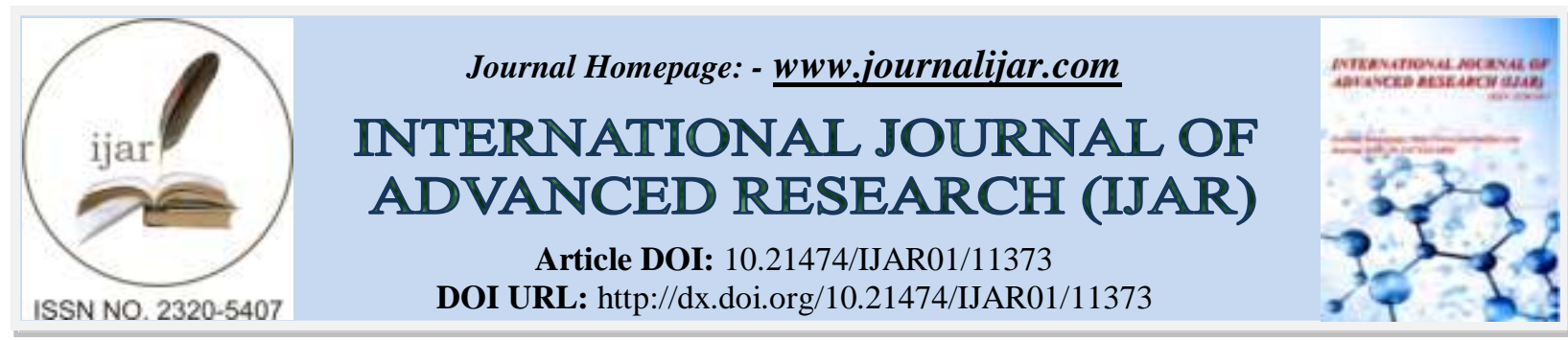

RESEARCH ARTICLE

\title{
ECOSYSTEM-BASED ADAPTATION TO CLIMATE CHANGE IN KAKAMEGA TROPICAL RAINFOREST ECOSYSTEM OF KAKAMEGA COUNTY, KENYA
}

John Ayieko Aseta, Prof. Paul Omondi and Dr. Abdirizak A. Nunow Department of Geography, Moi University, Eldoret, Kenya.

\section{Manuscript Info}

Manuscript History

Received: 20 May 2020

Final Accepted: 24 June 2020

Published: July 2020

Key words:-

Ecosystem-Based Adaptation (EbA),

Climate Change

\section{Abstract}

Africa is threatened by climate change, yet adaptive capacity of local communities continues to be weakened by ineffective and inefficient livelihood strategies and inappropriate development interventions. Practical and good activities for adaptation in Kenya is urgently and much needed to support adaptation actions, interventions and planning. The adaptation role of forest ecosystems has not been as prominent in the international discourse and actions as their mitigation role. This study therefore focused on the forest ecosystems as one of the natural resources used for adaptation to climate change impacts. The objective of this study was to evaluate Ecosystem-based Adaptation (EbA) to climate change in Kakamega Tropical Rainforest Ecosystem. This study was descriptive and cross-sectional in design and relied on a mixed methods methodology. Anthropogenic Global Warming Theory and Adaptive Management Theory were used to guide the study. A conceptual framework showing the interrelationship between the dependent and independent variables was outlined. The study utilized both secondary and primary data. The target population was 20,000 households living up to $10 \mathrm{~km}$ from the forest edge in the selected communities neighbouring Kakamega Tropical Rainforest and 20 government officials within Kakamega County. A total of 184 members of the households and 20 forest officers were sampled as respondents in the study. The study findings revealed that EbA are measures which use ecosystem services to attain or support adaptation to climate change. The EbA initiatives included; policy and behavioral changes, targeted management, conservation activities, restoration of highly degraded dry forest and reducing biodiversity loss. It was concluded that forest ecosystems help to adopt or mitigate climate. The study recommended that there is need to conserve the forest to get rid of extreme temperatures and precipitation since it was a source of many services to the surrounding communities and that the forest ecosystem also helped to adapt or mitigate climate change among others.

Copy Right, IJAR, 2020,. All rights reserved.

\section{Introduction:-}

Some researchers have evaluated the impacts of different climate change scenarios on alternative spatial policy options (Bryan et al., 2011), mapped ecological values of habitat of threatened species due to climate change (Bryan 
et al., 2011), examined the variation of nutrient retention in tidal mangroves with rainfall variation (Adame et al., 2010), considered species' responses to climate change as one of the indicators for investment decisions (Crossman et al., 2011), conceptualized the adaptive capacity through learning from historical examples (Bussey et al., 2012), and assessed usefulness of agro forestry systems for carbon sequestration and other Ecosystem Services in the face of climate adaptation and mitigation (George et al., 2012).

Bennett et al., (2009) in a survey, presented three hypotheses to accomplish improved management of relationships among multiple ecosystem services. First and foremost, an integrated socio-ecological strategy may give a superior evaluation or identification of relationships. Secondly, understanding the mechanisms that influence responses of multiple services to a specific driver may help identify points of management intervention that can yield maximum benefits. Thirdly, managing the relationship among ecosystem services can enhance ecosystem resilience and continuous provision of services, and prevent a sudden shift in the provision of ecosystem services.

Adaptation planning typically incorporates "hard" and "soft" approaches. Soft approaches are usually employed first and refer to policy and behavioural changes (Clark et al., Jones, Hole, and Zavalta, 2012). Hard infrastructure refers to manmade infrastructure, such as "dams, irrigation systems, reservoirs, dykes, seawalls, levees, river channelization, and rip-rapping (Clark et al, 2012). Jones et al. (2012) considers EbA approaches the third category of adaptation approaches, as it requires a combination of both hard and soft approaches. As Jones et al. (2012) explains, "EbA is generally deployed in the form of targeted management, conservation and restoration activities, and are often focused on specific ecosystem services with the potential to reduce climate change exposures".

Ecosystem based Adaptation is a novel strategy to planning and adaptation that prioritizes ecosystem services, enhancing biodiversity, as well as human health and wellbeing (Colls, Ash, and Ikkala, 2009). The idea evolved from the association between EBM and climate change adaptation actions. EBM is "an adaptive way to managing human activities that seeks to ensure the coexistence of healthy, fully functioning ecosystems and human communities. The intention is to maintain those spatial and temporal attributes of ecosystems such that component species and ecological processes can be sustained, and human wellbeing supported and improved" (Price et al., 2008).

As depicted above, climate change adaptations are activities taken to diminish the negative impacts or take advantage of new opportunities of climate change. Ecosystem based Adaptation is a combination of both of these EBM and climate change adaptation and remains relatively new in practice but is being deemed "a cost effective operational tool that can complement, if not substitute, traditional hard infrastructure practices" (UNEP, 2012).

Traditionally, EBM is applied in resource management issues from forestry to fisheries practices. EBM is a planning approach that incorporates multiple issues into one management strategy, from individual species to whole ecosystem functions (Travers, Elrick, Kay, \& Vestergaard, 2012). EBM is an innovative management regime because it acknowledges the rich complexity of ecosystems and attempts to identify, protect, and where necessary, restore important interactions. More specifically, EBM considers human activity in the specific management context and allows multiple activities to be managed for a common outcome (UNEP, 2012).

EBM focuses on a holistic approach to support an optimal management response (Travers, Elrick, Kay and Vestergaard, 2012). When climate change adaptation and EBM are practiced in tandem, the result should be a systems-based strategy "that considers all significant drivers and reactions to change, including, climate-driven change, disaster risk response, climate variability, and broader long-term socio-economic change" (Travers, Elrick, Kay and Vestergaard, 2012). A fundamental feature of Ecosystem based Adaptation is the consideration of existing ecosystem services and how they are used for human wellbeing (Huq et al., 2013; Munang et al, 2013).

National Adaptation Plan (NAP) system in Colombia was developed by the government in 2011 to address climate change, defining guidelines for various segment and regions to lessen vulnerability and incorporate climate change and climate variability in their planning approaches. In total 11 territorial climate change adaptations have been formulated (Huq et al., 2013). The EbA and Eco-DRR measures currently implemented include: rehabilitation of wetlands to reduce flooding risk and drought related to climate change and variability, and adaptation measures to mitigate climate change on the water yield and hydrological regulation capacity of wetlands and high mountain ecosystem. Other key ecosystems they considered are Moors (Paramo, Andean woodlands), high Andean forest, cloud forest and tropical forest (Lo, 2016). 
Restoration of highly degraded dry forests in Colombia was implemented by the Alexander von Humboldt Research Institute of Biological Resources, along with other institutions in the Ituango Municipality, Department of Antioquia (McBreen, 2016). The restoration activities will be accomplished through three pilot projects to compensate environmental harm brought about by the construction of a reservoir, and to add to the conservation of the delicate dry forest ecosystem of the region. The project will work as a reference for compensation (McBreen, 2016).

Some examples of ecosystem-based approaches for adaptation include: the maintenance and restoration of "natural" or "green" infrastructure for example mangroves, coral reefs as well as watershed vegetation as buffer zones that reduce climate risks (e.g. the use of coastal ecosystems to reduce risk of flooding and erosion from storm surges and rise in sea-level); the maintenance of agricultural landscapes to support productivity and avoid soil erosion under changing conditions e.g. introduction of agro forestry and soil conservation practices in the upstream areas of water catchments to avoid soil erosion, siltation, and large changes in hydrological regime (CBD, 2009).

While adopting this approach is cost-effective and locally appropriate, it also contributes to reduction of biodiversity loss and maintaining or improving ecosystem services that support livelihoods and economic activities (for example fish spawning as well as nurseries in protected mangroves and tourism in sustainable managed coastal areas) (CAN, 2009). Thus, this approach can serve multiple roles and gives multiple benefits (for example conservation of tropical forests supports a range of products critical for poor communities, protects against erosion, contributes to mitigation through both maintaining and increasing carbon storage, increases water storage capacity, provides wood fuel, maintains biodiversity and offers renewable raw materials and shelter) (CAN, 2009). Given the above, this approach is not only of high value for adaptation, but is aligned with local needs, capabilities and development objectives.

Convention on Biological Diversity explained the idea of Ecosystem based Adaptation in the year 2009 and on its twelfth COP in 2014, advances a stronger purpose for biodiversity conservation and implementation of EbA to climate change mitigation and adaptation, so as to enhance disaster risk reduction in local and national strategies as well as in National Adaptation Plans (NAPs) (Estrella et al., 2016). Ecosystem-based Adaptation (EbA) utilizes biodiversity and ecosystem services as part of an overall adaptation strategy to assist people and communities adapt to the negative impacts of climate change at local, national, regional and global levels (UNEP, 2014).

Approaches include sustainable management, conservation and restoration of ecosystems for the purpose of providing services to help people adapt to climate change impacts. Specifically, for terrestrial forest communities, EbA may include interventions of conserving or restoring forest on the land slope to reduce landslides or losses of water (Pramova et al. 2012); or developing diversified agroforestry to deal with climate variabilities (Thorlakson, T. and Henry, N. 2012); and conservation of agro biodiversity to give particular gene pools for crops or livestock to adapt to climate change.

EbA as a natural answer to climate change has been acknowledged to also have many co-benefits beyond the adaptation (UNDP 2015). Studies have shown that EbA can be more cost-effective and accessible to rural communities than adaptation interventions that use hard infrastructures or engineering methods (Jones et al. 2012, Vignola et al. 2015). In rural areas, Ecosystem based Adaptation usually overlaps with other socio-economic goals such as sustainable development and poverty alleviation, especially for smallholder farmers (Munang et al., 2014). In terms of evaluating the outcome of EbA, $63 \%$ of peer-review papers and $31 \%$ of grey literature show quantifiable evidence of success (Doswald, 2014).

Additional ways in which ecosystems function that can be connected to climate change disaster risk reduction is the protection of forests against landslides or avalanches in mountainous areas for example measures are being implemented in the Alp area by the Swiss government to protect villages (Uy, 2012). Catchment areas forests can decrease the risks of floods by increasing infiltration of rain and delaying peak floodwater flows. Floodplains as well as Wetlands can control floods in coastal areas or inland river basins. In dry lands, vegetation cover can function as physical firebreaks, ameliorate droughts and control desertification (Uy, 2012).

Munang et al., (2013) points out that Ecosystem based Adaptation gives a lasting and sustainable set of solutions in a cost effective manner to deal with climate change and sustainable development constraints. It is pointed out that in situations where measures of hard infrastructure utilized to be implemented, for example for coastal protection ecosystem-based solutions could offer a cost effective alternative. 
The major benefit of Ecosystem based Adaptation over other adaptation strategies is the provision of multiple cobenefits to society (Munang et al., 2013). Emerging literature promotes Ecosystem based Adaptation as applicable to both developed and developing countries (Munang et al., 2013). The co-benefits of Ecosystem based Adaptation help attain multiple policy and environmental goals to address climate change. For instance, protecting or restoring natural infrastructure such as barrier beaches, mangroves, coral reefs, and forests buffers human communities from natural hazards, erosion, and flooding (Munang et al., 2013).

A part from economic and environmental advantages of Ecosystem based Adaptation, there is tremendous opportunity to improve the social experience of people residing in close proximity or visiting green spaces in urban regions. The significance of green spaces and intact ecosystem for residents are many and extensively cited in the literature (Elmqvist, 2015; Zupancic, 2015; Demuzere et al., 2014; Zhou and Parves, 2012).

Ecosystems that are health can play an important purpose in disaster risk reduction. They can serve as natural buffers or protective barriers to floods and landslides. They can also effectively serve as water filtration and absorption systems (Renauld et al., 2013). Ecosystems that function fully can additionally build resilience against disasters by sustaining human livelihoods and giving essential goods to local populations, such as food and shelter. As a result, the Ecosystem based Adaptation and Disaster Risk Reduction practitioner communities are now joining together to explore how to better use nature-based measures to reduce the damage caused by disasters, involving those increased by climate change (Zhou and Parves, 2012).

In order to understand the interactions between climate change, disasters, and ecosystems, and to effectively plan solutions at the local level, participatory tools are appropriate alternatives as they allow combining indigenous knowledge with scientific information (UNDP, 2016). It also allows a better understanding of the perception of communities that are always the most vulnerable to climate change and disasters as they have limited access to those resources that would facilitate their resilience (CARE International, 2009). The 17 Sustainable Development Goals (SDGs) were adopted by the UN General Assembly in September 2015 and came into effect in January of 2016. It is also a 15-year agenda that aims to protect the planet and ensure prosperity for all. Some of these goals refer to the role of ecosystems services for climate change adaptation and disaster risk reduction (UNDP, 2016).

One thing to be noted with regard to shortcomings relates to lack of a universally accepted definition of EbA. Other sources conclude that this may be a reason why decision makers hesitate in undertaking Ecosystem-based Adaptation* with consideration of other adaptation options (Doswald et al., 2014). It is also vivid that Ecosystembased Adaptation can come in many forms. Combined with the unclear definition, the field becomes rather blurry making it increasingly difficult to compare amongst different Ecosystem-based Adaptation measures.

\section{Discussion of Research Findings:-}

The objective of this study was to evaluate Ecosystem-based Adaptation to climate change in Kakamega Tropical Rainforest. In order to address this objective, the researcher sought answers to several questions. The results are presented in Table 1 below.

Table 1:- Ecosystem-based Adaptation to Climate Change in Kakamega Tropical Rainforest.

\begin{tabular}{|c|c|c|c|c|c|c|c|c|c|}
\hline \multirow[t]{2}{*}{ ITEM } & \multirow[t]{2}{*}{ CATEGORY } & \multicolumn{2}{|c|}{ Agreed } & \multicolumn{2}{|c|}{ Undecided } & \multicolumn{2}{|c|}{ Disagreed } & \multicolumn{2}{|c|}{ Total } \\
\hline & & $\mathbf{F}$ & $\%$ & $\mathbf{F}$ & $\%$ & $\mathbf{F}$ & $\%$ & $\mathbf{F}$ & $\%$ \\
\hline \multirow{2}{*}{$\begin{array}{l}\text { EbA are measures which } \\
\text { use ecosystem services to } \\
\text { attain or support adaptation } \\
\text { to climate change }\end{array}$} & HM & 25 & 21.0 & 7 & 5.9 & 87 & 73.1 & 119 & 100 \\
\hline & FO & 20 & 100 & - & - & - & - & 20 & 100 \\
\hline \multirow{2}{*}{$\begin{array}{l}\text { EbA activities are policy } \\
\text { and behavioral changes }\end{array}$} & HM & 97 & 81.5 & 6 & 5.0 & 16 & 13.5 & 119 & 100 \\
\hline & FO & 20 & 100 & - & - & - & - & 20 & 100 \\
\hline \multirow{2}{*}{$\begin{array}{l}\text { EbA activities are targeted } \\
\text { management }\end{array}$} & HM & 89 & 74.8 & 16 & 13.4 & 14 & 11.8 & 119 & 100 \\
\hline & FO & 18 & 90 & 2 & 10 & - & - & 20 & 100 \\
\hline \multirow{2}{*}{$\begin{array}{lcc}\text { EbA activities } & \text { are } \\
\text { conservation activities } & \end{array}$} & HM & 87 & 73.1 & 10 & 8.4 & 22 & 18.5 & 119 & 100 \\
\hline & FO & 18 & 90 & 2 & 10 & - & - & 20 & 100 \\
\hline \multirow{2}{*}{$\begin{array}{l}\text { EbA are restoration of } \\
\text { highly degraded dry forest }\end{array}$} & HM & 87 & 73.1 & 10 & 8.4 & 22 & 18.5 & 119 & 100 \\
\hline & $\mathrm{FO}$ & 18 & 90 & 2 & 10 & - & - & 20 & 100 \\
\hline
\end{tabular}




\begin{tabular}{|l|l|l|l|l|l|l|l|l|l|}
\hline \multirow{2}{*}{$\begin{array}{l}\text { EbA activities is reducing } \\
\text { biodiversity loss }\end{array}$} & $\mathrm{HM}$ & 87 & 73.1 & 15 & 12.6 & 17 & 14.3 & 119 & 100 \\
\cline { 2 - 10 } & FO & 20 & 100 & - & - & - & - & 20 & 100 \\
\hline $\begin{array}{l}\text { Do you think forest } \\
\text { ecosystems help to adopt or } \\
\text { mitigate climate }\end{array}$ & HM & 84 & 70.6 & 14 & 11.8 & 21 & 17.7 & 119 & 100 \\
\cline { 2 - 10 } & & 17 & 85 & 3 & 15 & - & - & 20 & 100 \\
\hline
\end{tabular}

Key: hm-household members. Fo-forest officers

The respondents were first asked if they agree or disagree with the statement that measures which use ecosystem services to attain or support adaptation to climate change is what is indeed the definition of Ecosystem-based Adaptation. On this question, a majority at $87(73.2 \%)$ disagreed, $25(21 \%)$ agreed while only $7(5.9 \%)$ were undecided. On the same question, all the 20 (100\%) forest officers agreed with that definition.

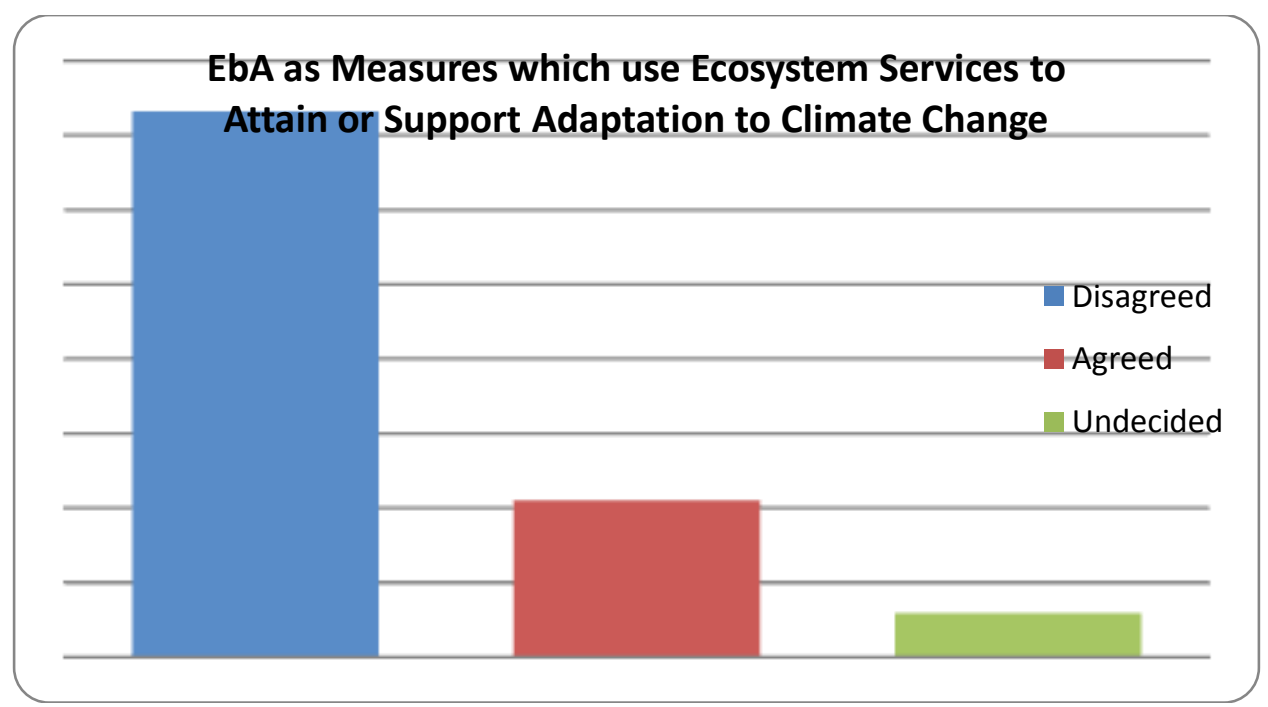

Figure 1:- EbA as Measures which use Ecosystem Services to Attain or Support Adaptation to Climate Change.

When the members of the households were asked whether Ecosystem-based Adaptation were policy and behavioural changes, a majority at $97(81.5 \%)$ agreed, $16(13.4 \%)$ disagreed, while only $6(5 \%)$ were undecided. On the other hand, all the $20(100 \%)$ of the forest officers agreed that indeed Ecosystem-based Adaptation were policy and behavioural changes. This is in line with the views of Pramova et al. (2012).

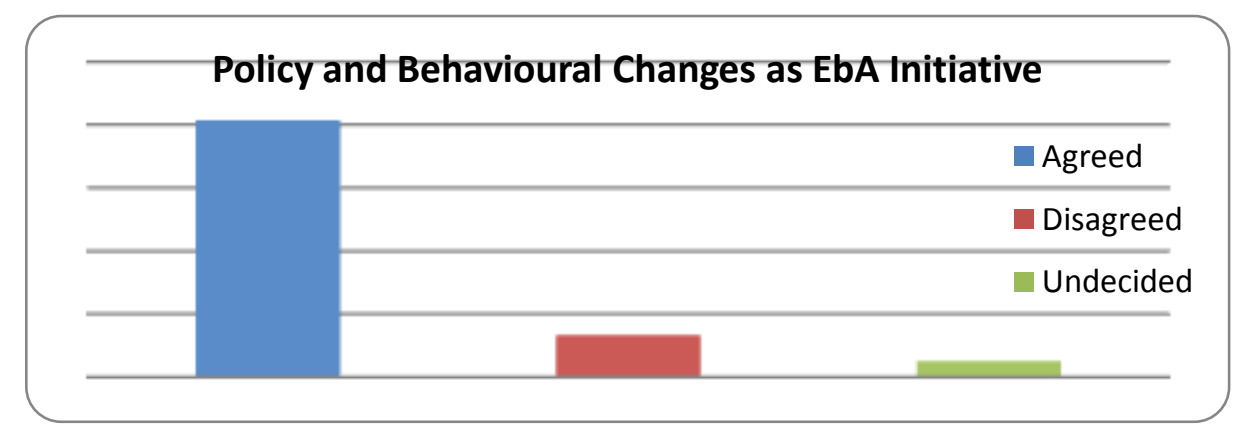

Figure 2:- Policy and Behavioural Changes as EbA Initiative.

When the members of the households were asked if the targeted management was among the EbA initiatives implemented in Kakamega Tropical Rainforest, a majority of the members of the household at 89 (74.8\%) agreed, $14(11.8 \%)$ disagreed and another $16(13.4 \%)$ were undecided. On the other hand, a majority of the forest officers at $18(90 \%)$ agreed and $2(10 \%)$ were undecided. 


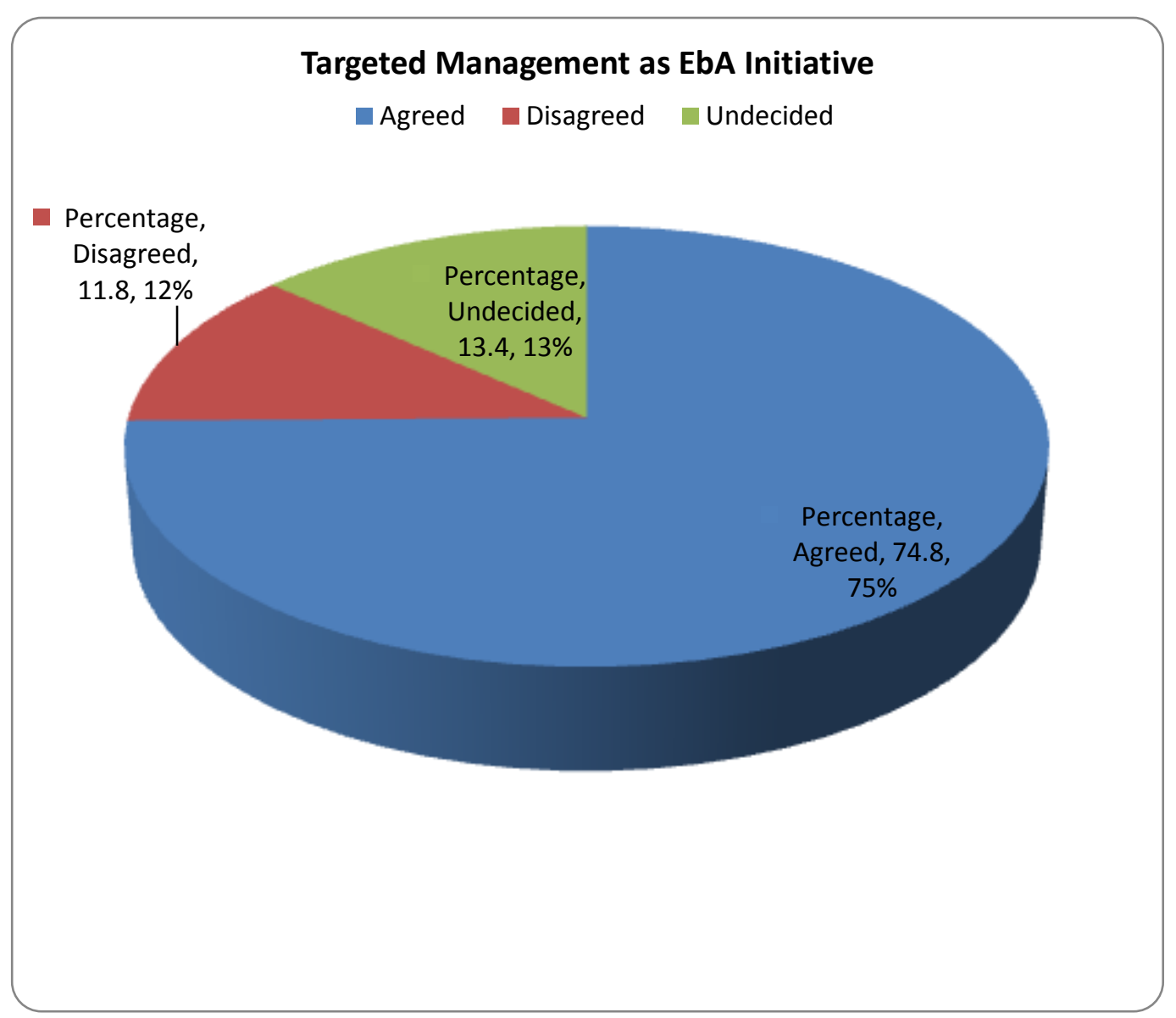

Figure 3:- Targeted Management as EbA Initiative.

On the issue of whether conservation activities were one of the EbA activities implemented in Kakamega Tropical Rainforest, a majority of the members of the households at $87(73.1 \%)$ agreed, $22(18.5 \%)$ disagreed while 10 (8.4\%) were undecided. On the other hand, the majority of the forest officers at $18(90 \%)$ agreed, while $2(10 \%)$ were undecided. Pramova et al. (2012) and Thorlakson, T. \& Henry, N. (2012) argue that EbA approaches include sustainable management, conservation and restoration of ecosystems for the purpose of providing services to help people adapt to climate change impacts. Specifically, for terrestrial forest communities, EbA may include interventions of conserving or restoring forest on the land slope to reduce landslides or losses of water or developing diversified agroforestry to deal with climate variabilities; and conservation of agro biodiversity to provide specific gene pools for crops or livestock to adapt to climate change.

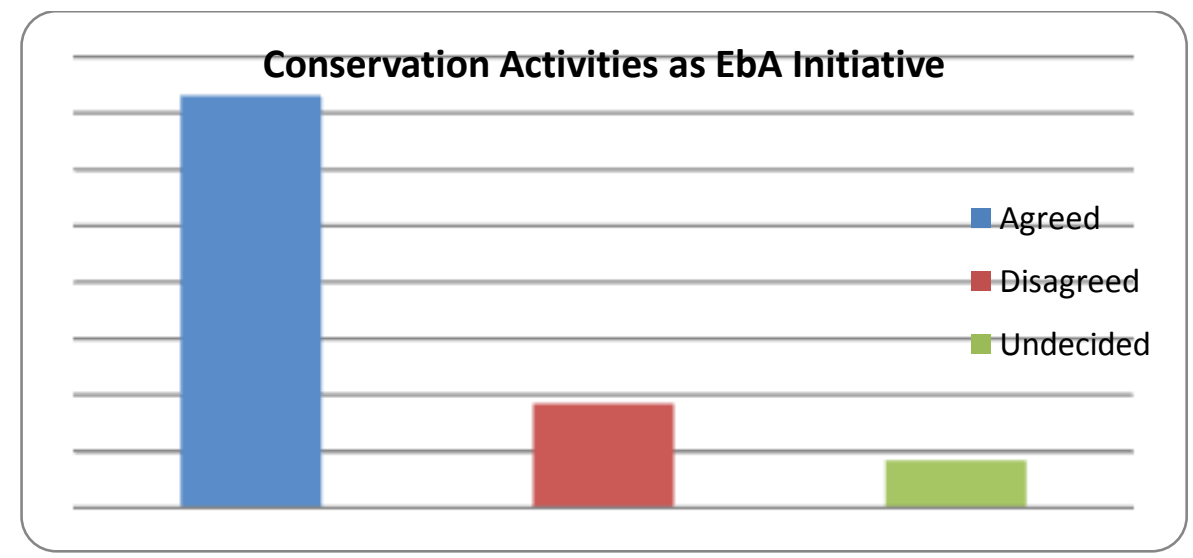

Figure 4:- Conservation Activities as EbA Initiative. 
The members of the households were also asked if the restoration of the highly degraded dry forest was one of the EbA initiatives implemented in the forest, and a majority at $87(73.1 \%)$ agreed, 22 (18.5\%) disagreed, while 10 $(8.4 \%)$ were undecided. On the other hand, a majority at $18(90 \%)$ of forest officers agreed and only $2(10 \%)$ were undecided. None disagreed.

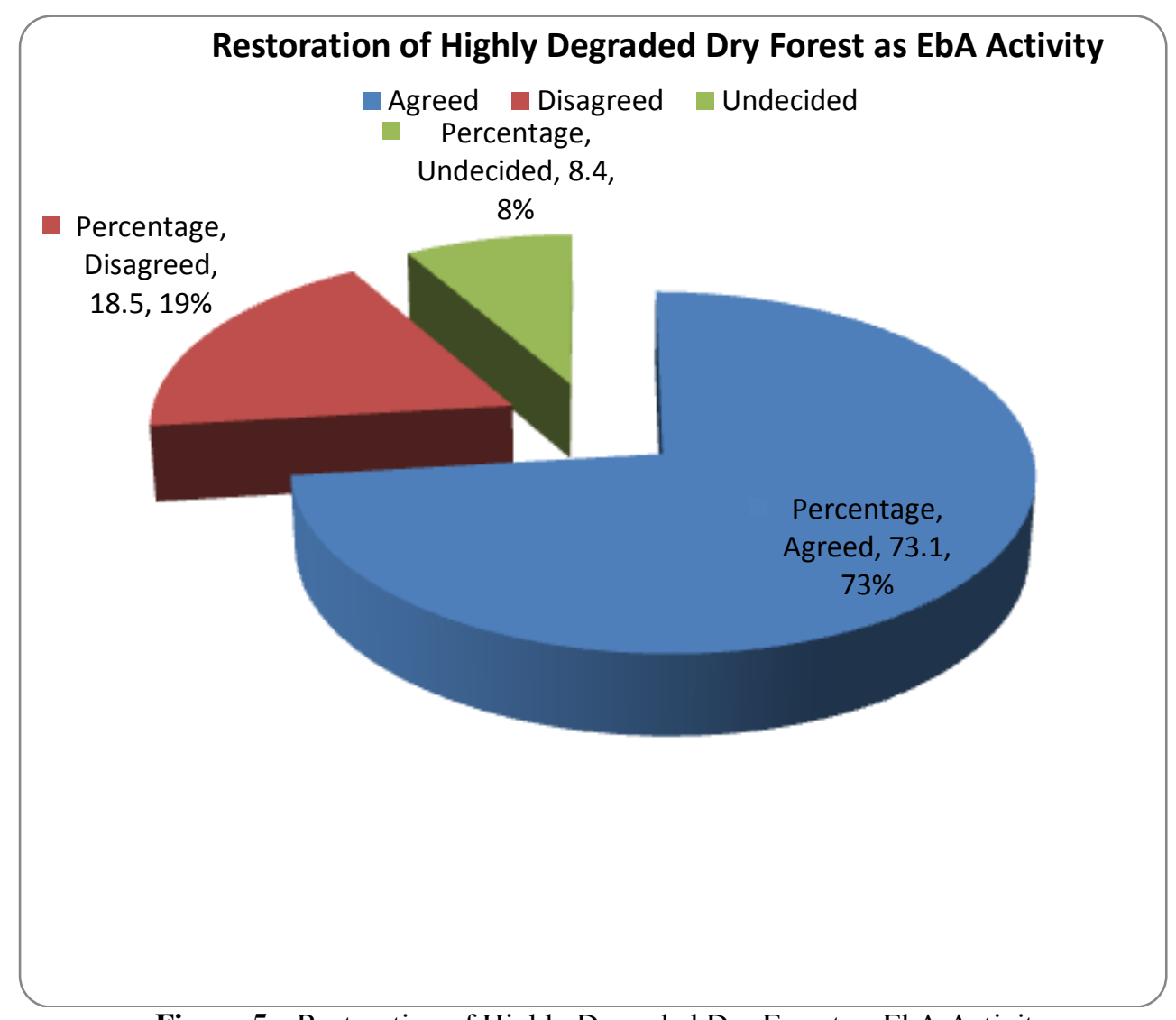

Figure 5:- Restoration of Highly Degraded Dry Forest as EbA Activity.

Asked if reduction on the biodiversity loss was one of the EbA initiatives implemented in the Kakamega tropical rainforest ecosystem, a majority at $87(73.1 \%)$ of the members of the households agreed, $17(14.3 \%)$ disagreed and $15(12.6 \%)$ were undecided. On the other hand, all the $20(100 \%)$ forest officers agreed. This shows that reduction of biodiversity loss was one of the EbA initiatives in the area as noted by Pramova et al. (2012) and Thorlakson, T. \& Henry, N. (2012).

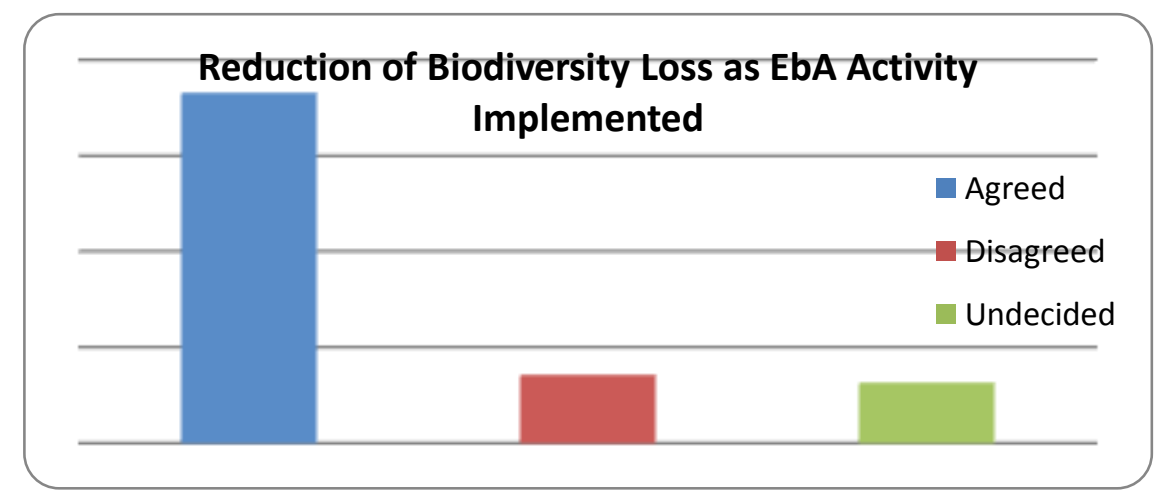

Figure 6:- Reduction of Biodiversity Loss as EbA Activity Implemented. 
When members of the households were asked their opinion if the forest ecosystem helped to adapt or mitigate climate change, a majority at $84(70.6 \%)$ agreed, $21(17.7 \%)$ disagreed, while $14(11.8 \%)$ were undecided. On the other hand, 17 (85\%) of the forest officers agreed and only $3(15 \%)$ were undecided. This agrees with the views of Pramova et al. (2012) and Thorlakson, T. \& Henry, N. (2012) that forests help to mitigate climate change.

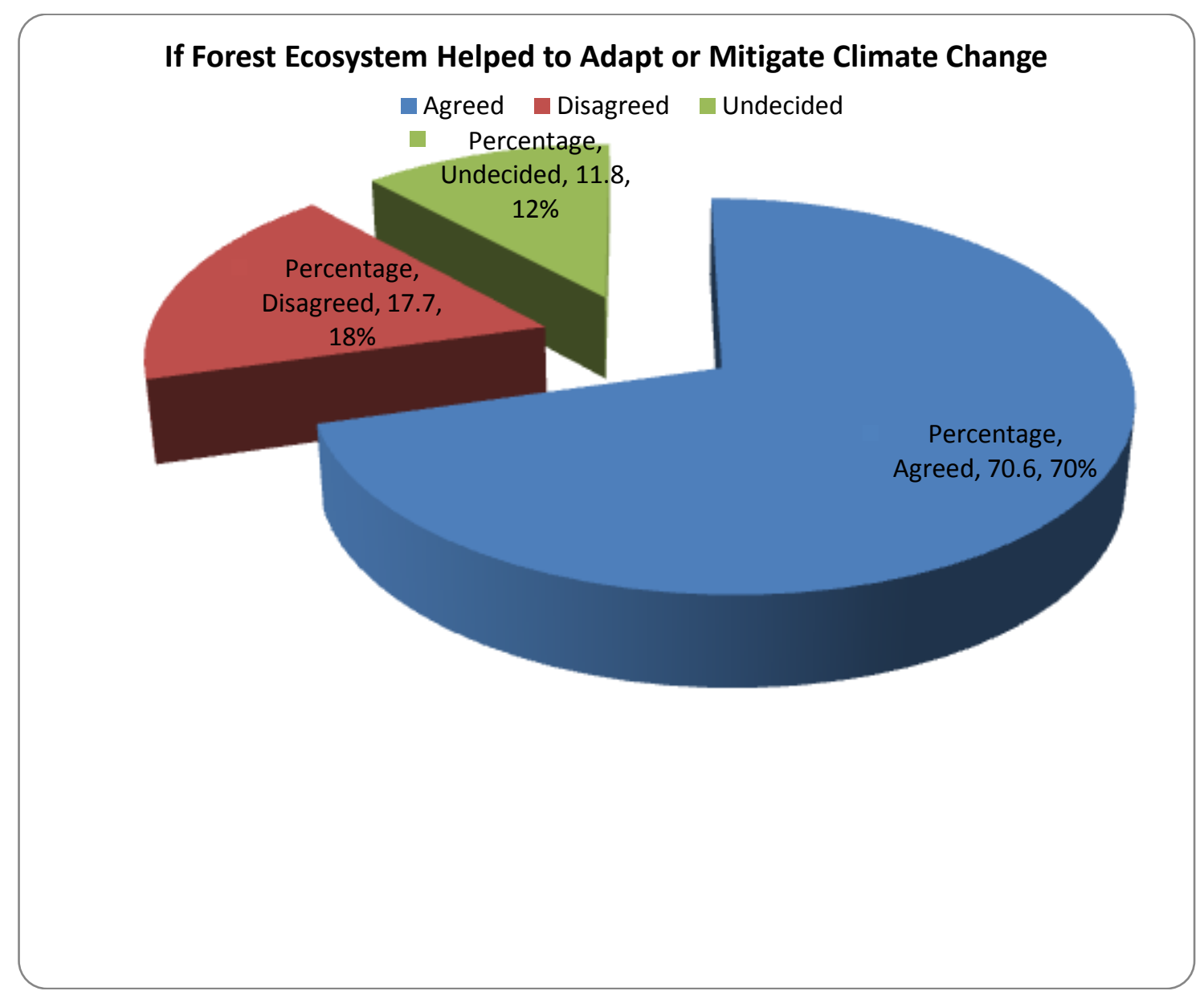

Figure 7:- If Forest Ecosystem Helped to Adapt or Mitigate Climate Change.

\section{Summary of the Findings:}

The respondents were first asked if they agree or disagree with the statement that measures which use ecosystem services to attain or support adaptation to climate change is what is indeed the definition of Ecosystem-based Adaptation. On this question, a majority of the household members disagreed while on the other hand a majority of the forest officers agreed with the statement.

When the members of the households were asked which Ecosystem-based Adaptation initiative, have been implemented in Kakamega Tropical rainforest, and if policy and behavioral changes were among the initiatives implemented, a majority of the members of the households agreed, while all of the forest officers agreed on the same.

Both the household members and forest officers agreed that the targeted management was among the EbA initiatives implemented in Kakamega Tropical Rainforest.

The members of the households were also asked if the restoration of the highly degraded dry forest was one of the EbA initiatives implemented in the forest, and a majority of both the members of the households and forest officers agreed. 
A majority of the members of the households and all the forest officers agreed that reduction on the biodiversity loss was one of the EbA initiatives implemented in the Kakamega Tropical Rainforest ecosystem. This shows that reduction of biodiversity loss was one of the EbA initiatives in the area as noted by Pramova et al. (2012) and Thorlakson, T. \& Henry, N. (2012).

When members of the households were asked their opinion, if the forest ecosystem helped to adapt or mitigate climate change, a majority of the members of the households and forest officers agreed. This agrees with the views of Pramova et al. (2012) and Thorlakson, T. \& Henry, N. (2012) that forests help to mitigate climate change.

\section{Conclusions:-}

Ecosystem based adaptation measures are services used to attain or support adaptation to climate change. Another initiative was restoration of the highly degraded dry forest, reduction on the biodiversity loss was also one of the EbA initiatives implemented in the Kakamega tropical rainforest ecosystem, the forest ecosystem also helped to adapt or mitigate climate change.

\section{Recommendations:-}

The organizations responsible ought to take the Ecosystem based adaptation measures to attain or support adaptation to climate change such as restoration of the highly degraded dry forest, reduction on the biodiversity loss was one of the initiatives implemented in the Kakamega tropical rainforest ecosystem, the forest ecosystem also helps to adapt or mitigate climate change.

\section{References:-}

1. Campos, Minerva, Alejandro Velázquez, and Michael McCall. (2014) "Adaptation strategies to climatic variability: A case study of small-scale farmers in rural Mexico." Land Use Policy 38 533-540.

2. CARE International, (2009) Climate Vulnerability and Capacity Analysis Handbook. URLhttp://careclimatechange.org/wpcontent/uploads/2014/12/CVCA_EN.pdf (accessed 08.08.17).

3. CBD (Convention of Biological Diversity) (2009) "Connecting biodiversity and climate change mitigation and adaptation: Report of the Second Ad Hoc Technical Expert Group on Biodiversity and Climate Change." Technical Series No. 41.Secretariat of the CBD, Montreal. [http://www.cbd.int/doc/publications/cbd-ts-41-en. pdf ]

4. Clark, J. S., D. M. Bell, M. H. Hersh, M. C. Kwit, E. Moran, C. Salk, A. Stine, D. Valle, et. al. (2011) Individual-scale variation, species-scale differences: inference needed to understand diversity. Ecology letters 14:1273-87.

5. Colls, A., N. Ash, and N. Ikkala. (2009) "Ecosystem-based Adaptation: A natural response to climate change." Gland, Switzerland: IUCN.

6. Demuzere, M., Orru, K., Heidrich, O., Olazabal, E., Geneletti, D., Orru, H., \& Faehnle, M. (2014) Mitigating and adapting to climate change: Multi-functional and multiscale assessment of green urban infrastructure. Journal of environmental management, 146, 107-115.

7. Doswald, N., Munroe, R., Roe, D., Giuliani, A., Castelli, I., Stephens, J., Möller, I., Spencer, T., Vira, B., \& H. Reid (2014) Effectiveness of ecosystem-based approaches to adaptaion: review of the evidence-base, In; Climate and Development, 6:2, pp.185-201

8. Estrella, M., Renaud, F.G., Karen Sudmeier-Rieux, Udo Nehren, (2016) Chapter 24: Defining New Pathways for Ecosystem-Based Disaster Risk Reduction and Adaptation in the Post-2015 Sustainable Development Agenda, in: Ecosystem- Based Disaster Risk Reduction and Adaptation in Practice. Springer International Publishing Switzerland, pp. 553-591. URL https://www.researchgate.net/publication/311487489 (accessed 08.23.17).

9. Howe, Caroline, et al. (2013): "Elucidating the pathways between climate change, ecosystem services and poverty alleviation." Current Opinion in Environmental Sustainability 5.1102-107.

10. Huq, N., Renaud, F., \& Sebesvari, Z. (2013) Ecosystem based adaptation to climate change - Integrating actions to sustainable adaptation. United Nations University, Institute for Environment and Human Security (UNU-EHS). Retrieved from: http://www.climate- impacts-2013.org/files/cwi_huq.pdf.

11. Jones, H. P., Hole, D. G., \& Zavaleta, E. S. (2012) Harnessing Nature To Help People Adapt To Climate Change. Nature Climate Change, 2(7), 504-509. 
12. Lo, V., (2016) Synthesis Report on Experiences with Ecosystem-Based Approaches to Climate Change Adaptation and Disaster Risk Reduction. Secretariat of the Convention on Biological Diversity. URL https://www.cbd.int/doc/publications/cbdts- 85-en.pdf (accessed 01.29.17).

13. McBreen, J., (2016) Regional Assessment on Ecosystem-based Disaster Risk Reduction and Biodiversity in South America. IUCN. URL https://www.iucn.org/sites/dev/files/content/documents/regional_assessment_ecodrr_and_biodiversity_in_south _america_2016_0.pdf (accessed 01.30.17).

14. Munang, R., Thiaw, I., Alverson, K., Liu, J., Han, Z., (2013) The role of ecosystem services in climate change adaptation and disaster risk reduction. Curr. Opin. Environ. Sustain. Terrestrial systems 5, 47-52. doi:10.1016/j.cosust.2013.02.002

15. Munang, Richard, et al. (2014) "Harnessing ecosystem-based adaptation to address the social dimensions of climate change." Environment: Science and Policy for Sustainable Development 56.1: 18-24.

16. Thorlakson, Tannis, and Henry Neufeldt. (2012) "Reducing subsistence farmers' vulnerability to climate change: evaluating the potential contributions of agroforestry in western Kenya." Agriculture \& Food Security 1.1: 15 .

17. Travers, A., Elrick, C., Kay, R., Vestergaard, O., Olhoff, A., Mills, A., \& Dews, G. (2012) Ecosystem-based adaptation guidance: moving from to practice.UNEP.Availableonlineat:http://www.unep.org/climatechange/adaptation/Portals/133/documents/Ecosy stemBased\%20Adaptation/Decision\%20Support\%20Framework/EBA\%20Guidance_WORKING\%20DOCUM ENT, 2030032012.

18. UNDP, United Nations Development Programme. (2015) "Generating multiple benefits from Ecosystem-based Adaptation in mountain ecosystems."

Retrievedfrom:http://www.adaptationundp.org/sites/default/files/downloads/undp_mt_eba_learning_brie f_2_final_w eb_04.01.16.pdf

19. UNITED NATIONS ENVIRONMENT PROGRAMME (UNEP) (2013) The Emissions Gap Report 2013 - A UNEP Synthesis Report, Nairobi

20. Uy, N. \& R. Shaw (2012) The Role of Ecosystems in Climate Change Adaptation and Disaster Risk Reduction; In Ecosystem-based adaptation; In: Community, Environment and Disaster Risk Management, Vol. 12, pp. 4159

21. Vignola R, Harvey CA, Bautista-Solis P, et al. (2015) Ecosystem-based adaptation for smallholder farmers: Definitions, opportunities and constraints. Agriculture, Ecosystems\& Environment 211: 126-132.

22. Zhou, X., \&Parves Rana, M. (2012). Social benefits of urban green space: A conceptual framework of valuation and accessibility measurements. Management of Environmental Quality: An International Journal, 23(2), 173189.

23. Zupancic, T. (2015) The Impact Of Green Space On Heat And Air Pollution In Urban Communities: A MetaNarrative Systematic Review. Retrieved from:http://www.davidsuzuki.org/publications/ImpactofGreenSpaceonHeatandAirPollutioninUrbanCommunitie s.pdf. 